\title{
Besorolási, szabványosított, normatív vagy „autorizált”
}

\author{
Ungváry Rudolf \\ Országos Széchényi Könyvtár \\ ungvaryr@gmail.com
}

In English at the introducing of the MARC the former "heading" name had to be changed because in the description of the resource it denominated the data from the point of view of its place. In Hungarian this change was not necessary because the Hungarian name does not mean heading, it names the data based on its purpose. Disregarding the logic counter-arguments, at present the well accepted former phrase has been replaced - it was introduced the "authorized" ("autorizált") data phrase. The present study describes the pros and contras in the present debate, points out the misinterpretation of the phrase which has been successfully used until these days, and demonstrates why the suggested phrase is misleading and inaccurate.

Angol nyelven azért kellett a MARC megjelenésével megváltoztatni a korábbi besorolási adatot jelento "heading” nevet, mert az a besorolási adat elhelyezése szempontjából nevezte meg az adatot a forrás leírásában. A magyarban azért nem kellett ezt megtenni, mert a „besorolási adat” név nem a helye, hanem a rendeltetése szempontjából nevezi meg az adatot. Az ellenérveket semmibe véve most bevezették helyette az „autorizált” adat kifejezést. A tanulmány részletesen ismerteti az érveket, az ellenérveket, és rámutat a "besorolási adat” kifejezés félreértelmezésére, a javasolt kifejezés félrevezető és hibás voltára. A „besorolási” jelző a maga tömörségével és szépségével nyelvi telitalálat volt.

\section{Egy terminológiai kérdés háttere}

Azért kellett angolul és németül a MARC előtti időkben kialakult "heading" és "Ansetzungsform" kifejezéseket megváltoztatni, mert ezek a helye szempontjából nevezték meg a tételt. Annak a helynek a szempontjából, amelyet a mindenkori dokumentumleirásban elfoglalt. A MARC-rekordban magát a "heading” és németül az „Ansetzungsform” kifejezést azonban továbbra is használták a rendszói részre és a közvetlenül hozzá kapcsolódó kiegészitő elemekre, és ez a magyarban továbbra is ugyanigy van. De maga az egész MARC-rekord nem csak a tételfejböl áll (lásd a 4. ábrát).

Ezzel szemben a „besorolási adat” kifejezés nem tételfejet jelent, holott a manuális gyakorlat idején valóban csak a tételfej képviselte ezt az adatot. Amikor tehát megjelent angolul az új „authority record” kifejezés, magyarul nem volt szükséges megváltoztatni a "besorolási adat” nevet. Már csak azért se, mert maga az MSZ 3440-es besorolási szabvány megszületésekor, 1979-ben (lásd a 3. ábrát) már létezett mint a Magyar Nemzeti Bibliográfia számítógéppel kezelt állománya. Ennek rekordjai lényegében a MARC-nak feleltek meg, még ha annak a magyar könyvtári szabványokhoz alkalmazott bibliográfiai MAMARC volt is. A HUNMARC, és annak besorolási formátuma 1988-ban jelent meg [5, 6, 7]. Hosszú ideig a "besorolási adat”, 
„besorolási rekord" kifejezés semmiféle értelmezési problémát nem okozott. 1998ban, tehát amikor a MARC már régen létezett, és a magyar HUNMARC besorolási adatcsere-formátum is készen volt, a "besorolási" jelző magyar használatát a MARC-rekordra senki se kifogásolta, holott angolul már évtizedek óta létezett az "authority" név. ${ }^{1}$

\section{Besorolási adat helyett „autorizált”. Érvek}

Körülbelül két-három év óta Magyarországon az „autorizált formátum”, „autorizált adat" és az „autorizálás" kifejezés használatára akarnak áttérni.

Pártolói azt állítják, hogy a „besorolási adat”, „besorolási rekord” elavult, mert

(1) ma már nincs szó besorolásról;

(2) csak a könyvtári besorolási szereppel rendelkező adatokat tartalmazza, nem tartalmazza a tartalmi feltárással kapcsolatos újabb metaadatokat és relációkat, az adatkezeléssel kapcsolatos metaadatokat

(2.1) a MARC21 "authority” rekord sokkal több adatelemet tartalmaz, mint amennyit a korai ISBD és MSZ szabványokban rögzitettek;

(2.2) a MARC21 „authority” nemcsak több, de komplexebb, sokféleséget kifejező adatok értendők, és az "autorizáláson” komplexebb tevékenység értendő, mint a besorolási adatok szabványositott formáinak kialakitása;

(2.3) mivel a digitális információs térben sokféle forrásból kell összeterelni és összehangolni a metaadatokat, ezért összetettebb kognitiv folyamatok zajlanak le;

(2.4) nem alkalmasak arra, hogy tágabb kontextusban is helyt álljanak. Nem beszélve olyan gyökeres ellentmondásokról, hogy az egységesitett besorolási adatok nem egységesek [8],

(2.4) „nem egyszerüsithetjük le a kérdéskört az egységesités és a besorolás nézöpontjaira [...] a reprezentálás elemibb adatok szintjén történik, a "besorolás" tényleg értelmezhetetlen ebben a közegben" [8];

(2.5) „Ma már egyenrangúak a névvariánsok, amelyek közül kiválasztható a kitüntetett névalak, a többi kezelése pedig az authority rekord feladata." [6]

(3) Az FRBR, FRAD, RAK a források kezelésének többszintü modelljén alapszik, ezen belül a megjelenési forma csak az egyik szint. [6]

$1 \quad$ A „besorolási adat” magyar kifejezés tehát 1998-ban is elfogadott volt, nem Vajda Erik találta ki egyedül, csak abban az évben regisztrálta egy elemzésében a név magyar használatának tényét a „besorolási rekord” esetére is. A HUNMARC esetében ugyanis azt már eleve használták azok, akik a változatait kidolgozták (és ezek a szakemberek, mint Sipos Márta, Szücs Jenőné nem azok közé tartoztak, akik az MSZ 3440 magyar szabványt 1976-ban létrehozták, hanem azok közé, akik a tényleges könyvtárinformatikai gyakorlatban ezt a rekordtipust tevőlegesen a Magyar Nemzeti Bibliográfához előállitották. Nekik semmiféle problémájuk nem volt a kifejezéssel - pedig ekkor már nem csak a tételfejet kellett meghatározni folyamatosan, hanem magát a rekordot is.

2 Az ellenérveket kifejtette Dudás Anikó [1, 2, 3] és a Katalisten Tóvári Judit [8] 
(4) a besorolási adat csak a hagyományos "heading element"-et, azaz a korai ISBD és MSZ szabványokban rögzitett tételfejet jelenti, nem pedig a teljes MARC21-rekordot.

\section{Ellenérvek}

Egyik indoklás sem igaz.

(1.1) A fentiekben már kimutattuk, hogy a besorolás nem csak azt jelenti, hogy valami konkrétat (esetünkben egy katalóguskártyát) egy rendezési elv alapján sorrendbe állitanak, elhelyeznek egy konkrét sorban (egymás mögé vagy elé, azaz sorrendben). Van egy általánosabb jelentése, amely szerint valamit egy adott fogalom terjedelmébe sorolnak be. Márpedig szaktárgyszavakkal (ahogy az osztályozási rendszerek jelzeteivel is) a forrásokat az általuk megnevezett konkrét dologhoz kapcsolják vagy az adott fogalom terjedelmébe sorolják. Ehhez nem szükséges semmiféle cédulakatalógus.

A nyelvhasználat is ezt bizonyitja:

"Hogyan érhetem el, hogy a Google minél egyszerübben besorolja az oldalamat a keresöbe?"

(1.2) Attól kezdve, hogy a MARC-formátum Magyarországon ismertté vált, az Országos Széchényi Könyvtár (OSZK) által bevezetett és használt besorolási rekord és adat minden félreértést kizárva használható volt a szakmában. 1970 óta, mióta MARC-formátumot használnak Magyarországon is (kezdetben HUNMARC formájában), senki sem emelt ellene kifogást, és nem számitott félreérthetőnek. Ha egy szabványban rögzítik, hogy az „authority data” besorolási adatot jelent, akkor teljesen egyértelmü a szakmai jelentése.

Ráadásul az MSZ 3440 besorolási szabványt csak 1979-ben adták ki. Kialakitásakor már egyrészt régen ismert volt a USMARC, másrészt már a hetvenes évektöl kezdve használták a MAMARC-ot is, majd a HUNMARC-ot a Magyar Nemzeti Bibliográfia számítógéppel történő előállitására. Magában a szabványban egyetlen egyszer nem fordul elö a katalóguscédula szó, vagy az, hogy besorolási adat alapján cédulák közé sorolják a katalógustételt. Azaz a szabvány készitői - akik közé a számítógéppel készitett Magyar Nemzeti Bibliográfia szerkesztője is tartozott - úgy hozták meg a döntésüket a szabványos „besorolási adat” megnevezéséről, hogy egyáltalán nem hagyták figyelmen kivül azt a tényt, hogy a gépesítés körülményei között már szó sincs cédulák közé sorolásról.

(1.3) A besorolási adat, vele a besorolási rekord kifejezés egyáltalán nem akadálya annak, hogy azt ne csak az ISBD és MSZ szabványokban leirt formára, hanem az újabb metaadatokat és relációkat, valamint az adatkezeléssel kapcsolatos többi metaadatot tartalmazó teljes MARC21-rekordra alkalmazzák.

Ezen se a FRAD, se az RDA nem fog változtatni, mivel csak az adattartalmat strukturálják. 
Az 1. ábrán modell szinten látható a rendeltetés szempontjából a MARC elötti és utáni helyzet.

a MARC elött:

tulajdonnév esetében a

eredményhalmaza:

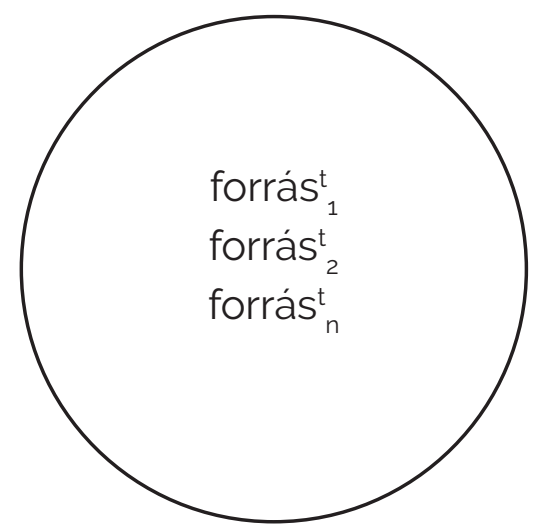

a MARC után:

tulajdonnév esetében a eredményhalmaza:

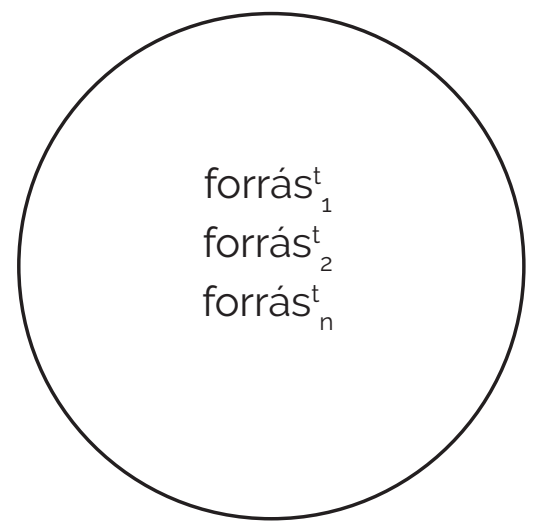

általános név (szaktárgyszó)

esetében a besorolási adat

eredményhalmaza:

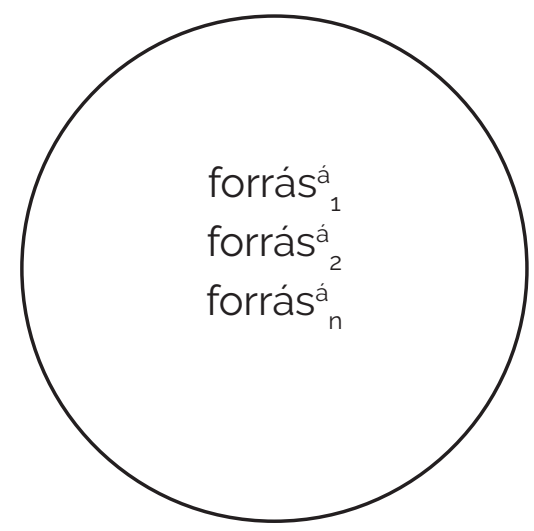

általános név (szaktárgyszó)

esetében a besorolási adat

eredményhalmaza:

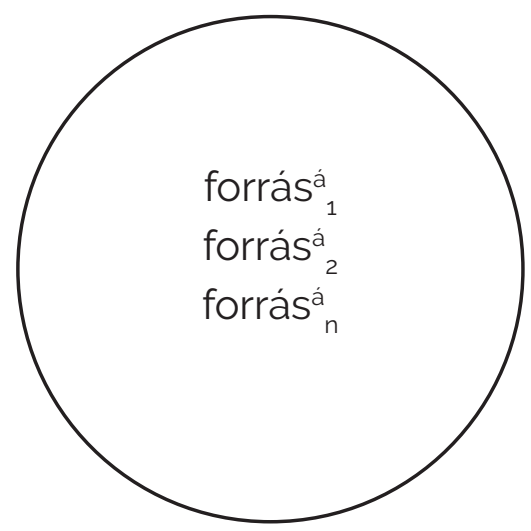

1. ábra Az „authority data", a "Normdaten" és a „besorolási adat” rendeltetési mintázata. Mindegyik esetben azonos forráshalmaz keletkezik!

Ez nem a programozás és a gépi tárolás szintje, hanem a koncepcionális modell szintje; továbbá nem a nevekröl önmagukban van szó, tehát szótárakról, névterekröl), hanem a logikai szinten létező MARC-rekordról 
(2.1) A MARC21 „authority” rekord valóban sokkal több adatelemet tartalmaz, mint amennyit a korai ISBD és MSZ szabványokban rögzítettek - csak éppen ettöl semmit se változik a rekord szerepe. Ugyanúgy arról van szó, hogy a MARC-rekord és az ISBD és MSZ szabványos besorolási tétel lényege, hogy a rekord/tétel tételfejével indexeljenek, „tárgyszavazzanak”, osztályozzanak forrásokat úgy, hogy azok a mindenkori állományban hozzáférési pontok legyenek. Az, hogy a MAR21 esetében a tételfejen (annak rendszaván, kiegészitő adatain) kivül még számos további, a tételfejre vonatkozó metaadat is van, a tényen semmit sem változtat.

(2.2) A többletadatok valóban sokfélék. Megállapításuk valóban több munkával jár. Ez azonban egyáltalán nem változtat azon a tényen, hogy a rekord ezen adatelemei egyrészt a besoroláshoz szükséges metaadatai, másrészt pedig a besorolás eredményeként a hozzáférési pontot alkotó tételfej metaadatai ("visszajelző referenciális" adatai). Márpedig miért ne lehetnének ilyen adatok egy olyan rekordban, melyet magyarul besorolásinak nevezünk? E többlet metaadatok léte mit változtat azon, hogy a rekord továbbra is hozzáférési pontként szolgál, azaz vagy egy megnevezett fogalom terjedelmébe sorolja a forrást, vagy egy tulajdonnévhez kapcsolva sorolja azt be?

Az "egységesitett forma megszerkesztését, összevetését stb." pedig a besorolási adatok megállapitásakor ugyanúgy el kellett végezni, ezen az, hogy a MARC21-rekordban több az adatelem, semmit sem változtat, hiszen a kevesebb vagy a több adatelem megállapítása egyaránt „komplex tevékenység".

(2.3) Az „információk összeterelése”, a „nem azonosakra vonatkozók megkülönböztetése" egyáltalán nem változás a MARC elötti idökhöz képest. Ez semmi mást nem jelent, mint amit a (2.2) pontban leirtunk: hogy a besorolási/ autorizált” adattal vagy meghatározott névhez kapcsolják, vagy meghatározott, szakkifejezéssel megnevezett fogalom terjedelmébe sorolják a forrást. A "névterek integrált, szemantikus, többcélú kezelését" pedig egyáltalán nem zárja ki, hogy az adattal besorolnak, hiszen éppen az ilyen, besorolt, tehát tartalmilag egyértelmüen azonositott adattal lehetséges elvégezni ezeket a kezeléseket. A "kognitiv folyamatok" a hagyományos, ISBD szerinti besorolási adatok használata és a velük végzett keresések alkalmával is ugyanúgy lejátszódnak, mint a mostani, gépesitett körülmények között (hiszen ezek nem a külvilágban, nem a technikában, hanem az elmében zajlanak).

(2.4) Attól, hogy a szabványosságot (mert az egységesités ezt fejezi ki) különféleképpen értelmezik, és ezért még a szabványos MARC21-rekordok se teljesen egyformák ugyanazon entitás esetében, nem változik az a tény, hogy a forrásokat ezekkel a MARC21-rekordokkal besorolják. Hogy a besoroláshoz használt rekordban több vagy kevesebb „elemibb” adat (értsd adatelem) van, attól még az állítás igazságtartalma változatlan marad. 
(2.5) Tóvári Juditnak az az ellenérve, hogy „ma már egyenrangúak a névvariánsok”, azt jelenti, hogy a névvariánsok (tehát a „lásd/helyett” relációkkal kapcsolódó gépi rekordok) mindegyike - helyesen, a számitástechnika jóvoltából hozzáférési pont lehet. Azaz mindegyik szerint besorolva van a forrás adott fogalom terjedelmébe, illetve adott névhez. Akkor meg miért ne lenne használható rájuk a besorolási adat? ${ }^{3}$

(3) Attól, hogyazFRBR, FRADésRAKmodellje megkülönböztetia mü, a kifejezési forma, a megjelenési forma és a példány szintjét, abból a szempontból, hogy mi a MARC21-rekord feladata, semmi se változik: ezeken a szinteken egyaránt be kell besorolni a forrást.

(4) Az angol „heading” (tételfej) valóban csak az ISBD és MSZ szabványokban rögzitett tételfejet jelenti, nem pedig a teljes MARC21-rekordot. Épen ezért kellett angol nyelvterületen a MARC-rekordok megjelenésével egy új kifejezést bevezetni. Az új kifejezés („authority”) azonban egyáltalán nem utal arra, hogy a korábbi "heading"-nél nagyobb adatról van szó. A feladata kizárólag az, hogy kizárja a MARC-rekord azonositását a tételfejjel (a "heading"gel). Csak éppen magyar nyelven nem kell a szakkifejezést megváltoztatni a MARC-rekord esetén, mert a besorolási rekord eleve nem jelenti, hogy csak tételfejröl van szó.

A MARC21 besorolási rekord tételfejen kivüli többi adatelemét azért nem kell a tételfejjel (vagy annak akárcsak egyetlen elemével is) együtt megjeleniteni hozzáférési pontként, mert azok a tételfej másodlagos avagy metaadatai. Ugyanakkor gépi rendszerben - ha olyan az adatbázis-kezelő rendszer - a besorolási rekord tetszőleges adateleme kereshetővé válik, azaz mindegyik besorolási adat lehet.

A felsorolt ellenérvekben nem általában „a magyar nyelv védelméről” van szó, hanem egy javasolt szakkifejezés történeti és szemantikai elemzéséröl. Elsösorban szakmailag érveltem amellett, hogy ez a névváltoztatás téves értelmezés eredménye.

A szaknyelv nyilvánvalóan más, mint a beszélt magyar nyelv, nem az a probléma, hogy egy kifejezés természetes nyelvü-e vagy sem. A besorolási adat is szaknyelvi kifejezés.

Az elemzéssel a döntés eredmémnyére, azaz az „autorizált” kifejezés félrevezetö voltára kivánok rámutatni szakszerü érvek alapján! Arra, hogy teljesen más okból választottak az angol-amerikai szakterületen a „heading” helyett „authority data” és „authority record" nevet, mint amit a magyar névváltoztatás javaslói állitanak. Azért

3 Azt a tényt, hogy "ma már egyenrangúak a névvariánsok" már 1998-ban Vajda Erik is megállapította. „Akkor" még senki se kifogásolta, hogy ezért helytelen a besorolási rekord kifejezése, és nem javasolta, hogy a besorolási rekord helyett az „autorizált rekord” kifejezést kellene használni! Ha „akkor" mindenkinek egyértelmü volt ez tény, akkor "ma”, 21 évvel késöbb (tehát több mint két évtized múlva) Tóvári Judit állítása miért érvényesebb, mint "akkor"? 
választották, mert a hagyományos angol ISBD-kifejezés (a "heading") nem volt alkalmas az új adat és rekord nevének azonositására, és nem önmagában azért, mert a MARC-rekordban sokkal több adat jelent meg, mint az ISBD-tételben, és mert összetettebbé vált a "szétszórt adatok összeterelése”. A magyar „besorolási adat" és "besorolási rekord" név ezzel szemben nem alkalmatlan arra, hogy a megnövekedett adattartalmú tételt azonositsa - mert nem pusztán tételfejet jelent - és a használatát illetően valóban továbbra is besorolásról van szó. Az telfogadott "autorizált" jelző szolgai átvétele az angolból szakszerütlen, és kritikájának jelenlegi hiánya fényt vet a könyvtári szakma jelenlegi helyzetére.

Az „autorizáció” egy másik szaknyelvben - bankszerktoréban is megjelenik, ott hitelesitést, feljogositást, felhatalmazást, engedélyezést jelent. Szakkifejezésként ma az autorizációt csak az automatán végzett kártyaművelet esetében használják, és ez megfelel a "hitelesitési” jelentésének. Azt értik rajta, hogy az elfogadó (az automata) hitelesként ismeri fela bankkártyát és engedélyezi a további müveleteket. [4] Márpedig a MARC21 tételfejei és a hozzájuk kapcsolódó metaadatok, akárcsak az ISBD "heading"-je és "heading element"-jei nem felhatalmazás, engedélyezés, hanem szabványositás nyomán keletkező adatok. Egyszerüen azért, mert itt - ahogy a szabványos tárgyszavak esetén is - szabványositásról, és nem engedélyezettségröl van szó.

A „besorolási” helyett az „autorizált" névváltozta következtében egy idő múlva a szakma új nemzedékei számára érthetetlenné válik a korábbi szakirodalomban használt, „besorolási” jelzővel ellátott összes szakkifejezés.

Németül se az autorisierte Date kifejezést használják! A német gyakorlathoz hasonlóan legfeljebb átkeresztelhetö szabványos névadatra, szabványos névrekordra:

$\begin{array}{lll}\text { authority data } & \text { Normdaten } & \text { szabványos névadat } \\ \text { authority record } & \text { Normsatz } & \text { szabványos névrekord } \\ \text { authority file } & \text { Normdatei } & \text { szabványos névállomány } \\ \text { authorized } & \text { normiert } & \text { szabványos }\end{array}$

A változtatás igy is azzal járna, hogy egy idő múlva a szakma új nemzedékei számára érthetetlenné válik a korábbi szakirodalomban használt, „besorolási” jelzővel ellátott összes szakkifejezés. A „besorolási” jelző a maga tömörségével és szépségével nyelvi telitalálat volt. Hozzáértő szakemberek hozták létre, évtizedekig nem okozott problémát, és eleve annak figyelembe vételével született, hogy a MARC (és késöbb annak magyar megfelelöje) létezett.

\section{Epilógus}

Nem remélhetem, hogy ezzel az elemzéssel meg tudom változtatni a „besorolási” jelző megszüntetéséröl szóló végzetesen hibás döntést. Ennek a tanulmánynak a célja, hogy felsorolja az érveket az „autorizált” kifejezés ellen, és ezt párhuzamba állitsa azzal, hogy mekkora félreértés ez névváltoztatás. 
Amikor a múlt évben vita kezdődött a Katalisten a besorolási adat kérdéséröl, az érveimre - melyek lényegében megegyeztek azokkal, melyeket ebben az értekezésben felsoroltam - nem érkezett viszontválasz.

Azon a nemrég tartott megbeszélésen, melyen eldöntötték, hogy az „autorizált” kifejezést fogják használni, nem vehettem részt, érveimet nem adhattam elő.

\section{Irodalom}

[1] Dudás Anikó. Az autorizálás az információszervezés és -hozzáférés feladatkörében - definiálás és nemzetközi tapasztalatok. = Könyvtári Figyelö, 52. évf. 4. sz. (2006). http://www.ki.oszk.hu/kf/kfarchiv/2006/4/dudas. html\#top

[2] Dudás Anikó: Nevek, antik nevek - autorizálás: egy magyarországi felmérés eredményei. = Tudományos és Müszaki Tájékoztatás, 52. évf. (2005) 9. Sz.

[3] Dudás Anikó: Forrásleírás és hozzáférés. Az új angol-amerikai katalogizálási szabályzat (RDA) és kritikája. = Könyvtári Figyelö, 2013. január 3. 4. sz.

http://ki2.oszk.hu/kf/2013/01/forrasleiras-es-hozzaferes-az-uj-angolamerikai-katalogizalasi-szabalyzat-rda-es-kritikaja/

[4] Gál Erzsébet: Hitelkérelmek, banki ismeretek. 4.3.3. Autorizáció (felhatalmazás) folyamata. (2013) https://www.tankonyvtar.hu/en/tartalom/ tamop412A/o007_d3_hitelkerelem_jav_scorm/4_3_3_autorizacio_ felhatalmazas_folyamata_knqQLg6m4m260Xpo.html

[5] HUNMARC, a besorolási rekordok adatcsere-formátuma. Összeáll. Sipos Márta, Szabó Julianna, Ungváry Rudolf. Budapest, 2010. Tervezet.

[6] HUNMARC, a besorolási rekordok adatcsere-formátuma. Összeáll. Sipos Márta. Budapest, 1998 március. Tervezet.

[7] KSZ/4.1 HUNMARC. A bibliográfiai rekordok adatcsere formátuma. [Összeáll. Sipos Márta]. Budapest, 2002. március.

http://www.ki.oszk.hu/107/e107_files/public/hunmarc.pdf

[8] Katalist. [Vita az „autorizált” jelző alkalmazásáról] [Dancs Szabolcs és Tóvári Judit hozzászólásal. 2018. augusztus 24. http://katalist-to-feed.blogspot. com/2018/08/re-katalist-uj-rendszerhez-uj-zsargont_30.html https://listserv.niif.hu/pipermail/katalist/2018-August/038933.html https://listserv.niif.hu/pipermail/katalist/2018-August/038886.html 